\title{
Effect of Pilates method and conversation circles on the health of older adults
}

\section{Efeito do método Pilates e das rodas de conversa na saúde de idosos}

\author{
Davi da Silva Duarte, Clóvis Arlindo de Sousa, Carlos Roberto de Oliveira Nunes*
}

Universidade Regional de Blumenau (FURB), Blumenau, SC, Brazil

\begin{abstract}
Introduction: Health education practices associated with oriented exercises have potential beneficial effect on health promotion and prevention of chronic diseases. Objective: This study aimed to verify the effect of an intervention protocol using Pilates and conversation circles on the functional autonomy and quality of life of older adults in the context of the primary health care of Taió, SC, Brazil. Methods: This study applied a single case experimental design (ABAB), with 24 participants aged 60 years or older who changed phases with and without interventions performed with Pilates sessions and conversation circles. At the end of each phase, anamnesis interview applied with the WHOQOL-OLD inventory and the GDLAM protocol were individually performed. Results: Interventions were associated with increased functional parameters and quality of life as well as to reduced body mass index. Participants also reported improvement in emotional conditions, body harmony and global mobility. Conclusion: The Pilates Method assured increased functionality of the volunteers, and further studies should be carried out to evaluate the subjective indicators.
\end{abstract}

Keywords: Quality of Life. Exercise Movement Techniques. Health Education. Public Health. Physical Therapy.

\section{Resumo}

Introdução: Práticas de educação em saúde associadas com exercícios físicos orientados têm potencial efeito benéfico para a promoção de saúde e prevenção de agravos de doenças crônicas não transmissíveis. Objetivo: Verificar o efeito de um protocolo de intervenção com método Pilates e com rodas de conversa na autonomia funcional e na qualidade de vida de idosos. Métodos: Trata-se da aplicação de delineamento experimental de caso único (ABAB), com 24 participantes com 60 anos ou mais que alteraram fases com e sem intervenção,

\footnotetext{
DSD: MS, e-mail: davi-fisio@hotmail.com

CAS: PhD, e-mail: casousa@furb.br

CRON: PhD, e-mail: cnunes@furb.br
} 
durante 20 semanas, realizadas com sessões de rodas de conversa sobre saúde, 30 min., e de Pilates, 45 a 50 min., no contexto da atenção primária em saúde da cidade de Taió em Santa Catarina. Em cada fase de intervenção foram realizadas 10 sessões de Pilates e rodas de conversas, duas vezes por semana. Ao final de cada fase, foram realizadas entrevista, aplicação do inventário WHOQOL-OLD e do protocolo GDLAM. Resultados: As intervenções foram associadas com o aumento dos parâmetros funcionais e de qualidade de vida, bem como redução de índice de massa corporal. Os participantes também relataram melhora nas condições emocionais, harmonia corporal e de mobilidade global. Conclusão: $O$ método Pilates e as rodas de conversa sobre saúde asseguraram melhora da autonomia funcional e qualidade de vida dos participantes.

Palavras-chave: Qualidade de Vida. Técnicas de Exercício e de Movimento. Educação em saúde. Saúde Pública. Fisioterapia.

\section{Introduction}

Brazil presents demographic and epidemiological transitions characterized by increased incidence of noncommunicable chronic diseases and aging population. This requires adjustments of social policies, particularly those aimed at meeting the growing demands in health, social security and social assistance areas $(1,2)$.

Physiological losses accompany senescence, including reduction in bone mineral density, muscle strength, flexibility, cardiorespiratory fitness, and reduction of static and dynamic balance. Aging is understood as a natural process of gradual reduction of the functional autonomy and capacity and consequently of daily activities and quality of life. This reduction is more pronounced in sedentary and insufficiently active individuals $(1,3,4)$.

Older adults who engage in regular physical activity demonstrate greater independence and autonomy and are often considered healthy even in the presence of chronic diseases. An alternative to physical activity is the Pilates method. This method was developed by Joseph Pilates in the decade of 1920 and is based on a concept called contrology, which means consciously control of all body movements. Movements can be performed on the ground with weight/resistance of the own body, and with the help of accessories such as ball, dumbbells, ankle weights or specific devices. Direct benefits may involve increased strength and flexibility, trunk strengthening and stability, improved posture and balance, increased self-esteem and prevention and treatment of muscle pain $(4,5,6)$.

Studies have shown positive effects of the Pilates method on the physical fitness and health conditions of practitioners. There are studies on, among other topics, balance and strength (3), flexibility (4), pain (6), spinal mobility and pulmonary function (7), quality of life (8), body composition (9), functional capacity (10), and bone remodeling (10). However, most publications address the effect of the Pilates method for treating low back pain (11).

Considering that the percentage of physically inactive individuals increases with aging and that nearly $40 \%$ of people aged 65 and over do not do any physical activity in the four contexts (leisure, work, commuting and domestic activities) (12), strategies to increase empowerment and autonomy are important ways to change the way of living of people, since lifestyle involves a set of habitual daily activities that are incorporated in terms of attitudes, values and opportunities present in people's lives. People experience reality and make choices, determined by social, economic, cultural and environmental factors (13).

The primary health care is aimed at promoting individual and collective changes to the process of community empowerment to work on improving the health and quality of life of individuals with greater participation in the control of this process. In this sense, conversation circles are a strategy of health education practices that enable dialogic meetings, creating opportunities for production and reinterpretation of meanings, knowledge and practices about experiences among participants. Conversation circles go beyond the physical layout (circular) of participants. The conversation circle space intends to build new possibilities that open to thinking. It is a continuous movement of perceiving, thinking, acting and modifying, where participants can recognize each other as actors of their actions and their own ability to change (14).

Thus, this study aims to determine the effect of an intervention protocol with Pilates method and conversation circles on the functional autonomy and quality of life of older adults in the context of the primary health care of the city of Taió, Santa Catarina, Brazil. 


\section{Methods}

This is an intervention study with reversal between baseline (A) and intervention periods (B), A-B-A-B (15), carried out with older adults in the context of primary health care in the municipality of Taió, Santa Catarina, Brazil. Participants were exposed to repeated measurements by means of reversal design with successive comparisons between experimental and control groups by the insertion and removal of the independent variable, i.e., combined Pilates and conversation circles.

The sample consisted of 24 individuals distributed into 4 groups of 6 individuals, in accordance with Resolution No. 387 of June 8, 2011 of the Federal Council of Physical Therapy and Occupational Therapy, which establishes physical therapy assistance parameters for the practice of collective activities (16).
Inclusion criteria were people aged 60 or more selfsufficient in basic human needs, in satisfactory physical condition, and who agreed to voluntarily participate in this study.

Informed consent was obtained by reading and signing the Informed Consent Form. This study was approved by the Ethics Research Committee of the Regional University of Blumenau, under protocol number $544233 / 2014$.

The total study duration was 20 weeks with 20 conversation circle and Pilates sessions. During phase A, at baseline, participants remained without any intervention for five weeks. In step B, individuals participated in conversation circle and Pilates intervention sessions also for five weeks, twice a week. In sessions, conversation circles were held for 30 minutes, followed by Pilates for 45-50 minutes (Figure 1).

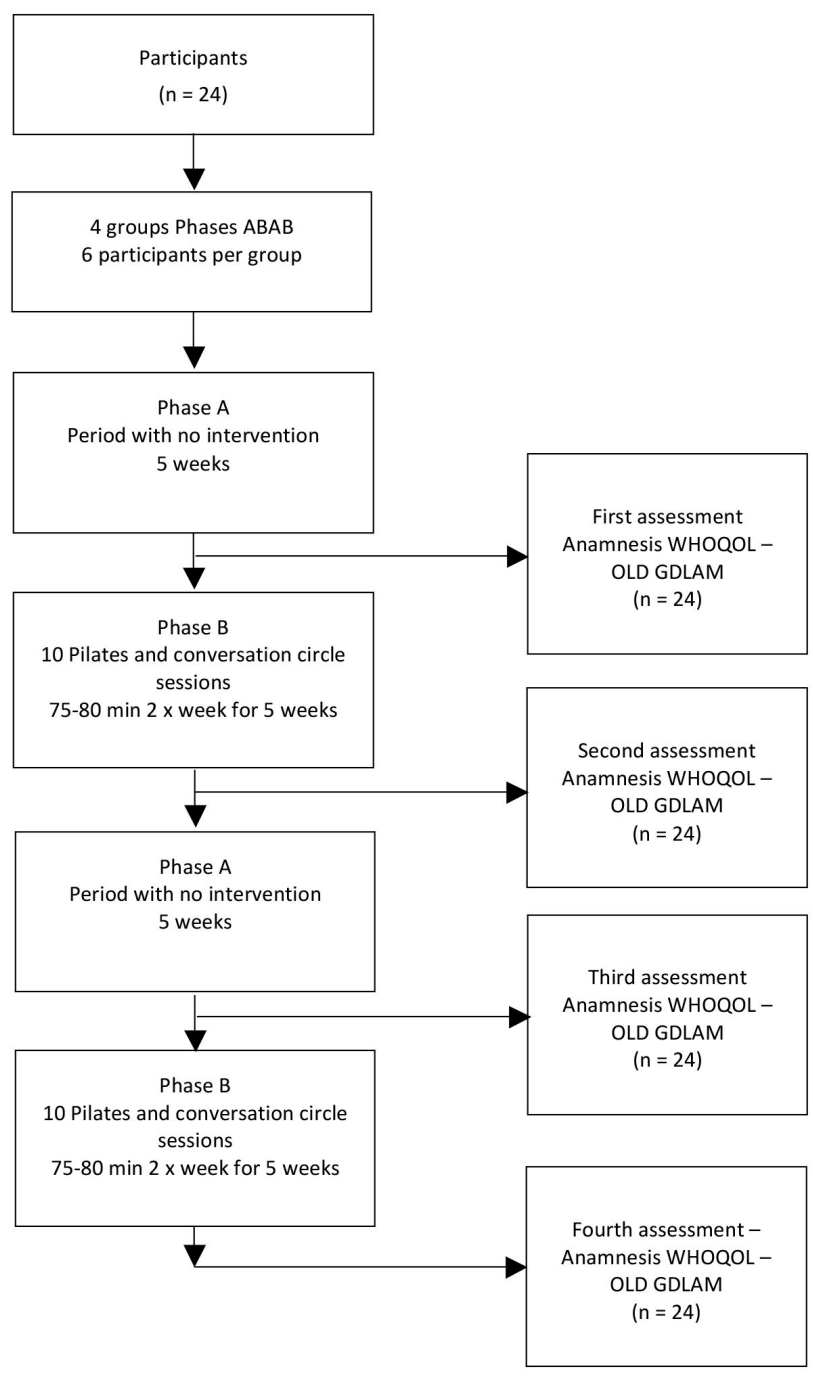


Figure 1 - Intervention study flowchart.

For conversation circles, the problematization methodology was used $(14,17,18,19)$. Participants were encouraged to critically observe their reality from their prior knowledge, linking it to the theme. Conversation circles were held in the early stages of the session, with everyone sitting on the floor making a circle. One participant was responsible for mediating discussions for each session with the help of health professionals. Participants had the opportunity to express their previous knowledge, analyze them, and reconstruct their knowledge about their life and health.

Topics were recommended by the expanded concept of health and those proposed in the WHOQOL-OLD quality of life domains: self-esteem, healthy eating, physical exercise, death, happiness, aging difficulties and selflove. The intervention took place in the morning in a large room equipped with the necessary equipment, located in a place called House of Culture, Municipal Department of Education.

The Pilates method was carried out with focus on strength, flexibility, balance, breathing and concentration improvements, as well as improvements in body awareness and posture. The exercise sequence was maintained throughout the study in order to achieve the maximum benefits and excellence in physical performance. Each exercise was carried out with 5 and 10 repetitions $(20,21)$. Warm-up exercise was composed of slow and fluid movements in order to increase concentration, prepare the body for further efforts and encourage deep and conscious breathing. Then, exercises for strengthening and flexibility were proposed: lower limbs (one leg circle and one leg kick), upper limbs (push-up and side bend) and trunk (hundred, side kick, swimming). The static and dynamic balances were also trained (rolling like a ball and crab) (Table 1).

Table 1 - Pilates Method Protocol

\begin{tabular}{|c|c|c|c|}
\hline Exercise & Objective & Variation/option & Time/number of repetitions \\
\hline $\begin{array}{l}\text { Slow and fluid movements / } \\
\text { Stretches }\end{array}$ & Warm-up & Upper, lower limbs and trunk & $10-15 \mathrm{~min}$ \\
\hline Hundred & Trunk & Flexed knees & $\begin{array}{l}10 \text { series with } 5 \text { inspirations and } 5 \\
\text { expirations }\end{array}$ \\
\hline One Leg Circle & Lower limbs & Small Leg Circles & 5 - 8 repetitions each leg \\
\hline Push-Up & Upper limbs & $\begin{array}{l}\text { Spacing training, knee } \\
\text { flexion }\end{array}$ & 5-8 repetitions \\
\hline Side Kick & Trunk & Side-Lying Straight Leg Lifts & 5 - 8 repetitions each side \\
\hline Rolling Like a Ball & $\begin{array}{l}\text { Static and dynamic } \\
\text { balance }\end{array}$ & Hands behind thighs & 8 - 10 repetitions \\
\hline One Leg Kick & Lower limbs & Hamstring Curls & 8 - 10 repetitions \\
\hline Side Bend & Upper limbs & The Twist & 5 - 8 repetitions each side \\
\hline Swimming & Trunk & Modified Swimming & 8 - 10 movements each side \\
\hline Crab & $\begin{array}{l}\text { Static and dynamic } \\
\text { balance }\end{array}$ & The Seal & 5 - 8 repetitions \\
\hline
\end{tabular}

At the end of all interventions, participants were asked to anonymously answer some questions assessing the group structure, the dynamics of meetings and the work of the professional. This material was delivered to be completed at home and brought in subsequent meetings.
Evaluations were carried out in four stages. At the end of each phase: 1) anamnesis and physical examination to collect personal and socioeconomic data, as well as weight and height to calculate body mass index (BMI); 2) application of the World Health Organization Quality of Life (WHOQOL-OLD); 3) Group inventory 
for evaluation of quality of life; and 4) application of the Latin American Development Group for Maturity (GDLAM) protocol to assess functionality.

WHOQOL-OLD rates quality of life for seniors in six areas distributed into 24 questions on a Likert scale: needs improvement, regular, good and very good and has the following self-evaluation categories: a) sensory functioning; b) autonomy; c) past-presentfuture activities; d) social participation; e) death and dying; f) intimacy. Each domain has 4 items, and in this sense, for all domains, the score of possible values range from 4 to 20 (22).

GDLAM protocol tests consist of: a) 10-m walking test (C10m); b) standing from a sitting position (LPS); c) standing from prone position (LPDV); d) standing from the chair and walk around the house (LCLC). Measurements were performed by the time in seconds and allow estimating functional autonomy capabilities. All of these tests can be used to calculate the GDLAM Index (GI). Lower scores in this instrument represent higher level of functional autonomy $(23,24)$. The GI is calculated as follows:

$$
I G=\frac{[(C 10 m+L P S+L P D V) * 2]+L C L C}{3}
$$

Table 2 shows the classifications for estimating functional autonomy through the GDLAM protocol, obtained by quartiles $(24,25)$.

Table 2 - Classification of functional autonomy by GDLAM protocol

\begin{tabular}{llllll}
\hline \multirow{2}{*}{ Classification } & \multicolumn{5}{c}{ Tests } \\
\cline { 2 - 5 } Weak & $\mathbf{C 1 0 m}(\mathbf{s e c})$ & LPS $(\mathbf{s e c})$ & LPDV (sec) & LCLC (sec) & GI (scores) \\
Regular & $>6.89$ & $>11.47$ & $>4.51$ & $>43$ & $>28.54$ \\
Good & $6.89-6.23$ & $11.47-9.86$ & $4.51-3.48$ & $43-38.69$ & $28.54-25.25$ \\
Very Good & $6.22-5.58$ & $9.85-8.35$ & $3.47-2.78$ & $38.68-34.78$ & $25.24-22.18$ \\
\hline
\end{tabular}

Note: $\mathrm{C} 10 \mathrm{~m}=10$-m walking test; $\mathrm{LPS}=$ standing from a sitting position; LPDV = standing from the prone position; $L C L C=$ standing from a chair and move around the house; $\mathrm{GI}=\mathrm{GDLAM}$ index.

Data were analyzed using descriptive statistics, including median, mean, standard deviation and maximum and minimum values. Parametric tests were applied for quantitative variables with normal distribution and non-parametric for nominal and ordinal variables, as well as for discrete variables when not normally distributed. For parametric analyses, Analysis of Variance for repeated measures and Tukey DHS were applied. For nonparametric analyses, Analysis of Variance of Friedman and Wilcoxon test were applied, with significance level of $p<0.05$.

\section{Results}

Of the 24 participants, 19 were females (79\%) and 5 males (21\%). The average age was 66 years (standard deviation of \pm 6 years) and median also 66 years (minimum of 60 and maximum of 78 years). After "B" intervention periods, Pilates method and conversation circles, participants performed the functional capacity protocol tasks faster than after in "A" baseline period. Significant reduction in body mass index and time of all GDLAM functionality tests were also obtained. After 20 weeks, the GDLAM index obtained $16 \%$ reduction in the average time of tests, from 32.5 to 27.3 seconds ( $p<0.001$ ). In the first 10 weeks, reduction was greater $(14 \%)$ than in the last 10 weeks (11\%) of intervention (Table 3). 
Table 3 - Comparison of body composition results and functionality tests (GDLAM) of older adults after intervention and baseline periods $(n=24)$.

\begin{tabular}{llllll}
\hline \multirow{2}{*}{ Variables } & \multicolumn{3}{l}{ Period / Evaluation (Mean \pm SD) } & & \\
\cline { 2 - 4 } & Baseline "A"/First & $\begin{array}{l}\text { Intervention "B"/ } \\
\text { Second }\end{array}$ & Baseline "A"/Third & $\begin{array}{l}\text { Intervention "B"/ } \\
\text { Fourth }\end{array}$ & p \\
\hline BMI (kg/m) & $27.29 \pm 4.25$ & $26.98 \pm 3.95$ & $27.21 \pm 3.89$ & $26.74 \pm 3.92$ & $<0.001$ \\
C10m (sec) & $7.11 \pm 1.05$ & $5.68 \pm 1.08$ & $6.43 \pm 1.08$ & $5.21 \pm 1.10$ & $<0.001$ \\
LPS (sec) & $12.73 \pm 2.21$ & $10.15 \pm 2.16$ & $11.29 \pm 2.21$ & $9.43 \pm 1.66$ & $<0.001$ \\
LPDV (sec) & $4.99 \pm 1.39$ & $3.67 \pm 0.92$ & $4.53 \pm 1.41$ & $3.76 \pm 1.38$ & $<0.001$ \\
LCLC (sec) & $47.92 \pm 5.07$ & $44.64 \pm 5.39$ & $47.49 \pm 5.55$ & $45.17 \pm 5.28$ & $<0.001$ \\
G I (sec) & $32.52 \pm 3.90$ & $27.88 \pm 3.92$ & $30.65 \pm 4.05$ & $27.31 \pm 3.79$ & $<0.001$ \\
\hline
\end{tabular}

Note: $\mathrm{C10m}=10-\mathrm{m}$ walking test; LPS = standing from a sitting position; LPDV = standing from the prone position; LCLC = standing from a chair and move around the house; GI = GDLAM index.

The 10-m walking test in the first line was weak, with 7.11 seconds. After intervention, it improved to good. When intervention was over after 5 weeks, average of regular classification was obtained, and in the final 5 weeks of intervention with Pilates and conversation circles, the classification of the 10-m walking test improved to very good. Comparing Table 3 to Table 2 , the time of the standing from a sitting position test was weak in the first baseline and after 20 weeks showed good classification. The standing from the prone position and standing from a chair and move around the house tests improved from weak to regular, as well as the GDLAM index.
Table 4 shows the results of the quality of life selfassessment by the WHOQOL-OLD. Higher results indicate better levels of quality of life for this domain and for overall quality of life. Participants maintained their classification for self-analysis of quality of life as regular or good, even showing positive changes in their scores. Global mobility improved from weak to regular or good. Health, body and emotional situation self-analysis also improved from regular to good. Global mobility was considered weak at baseline and improved to good after the intervention phases.

Table 4 - Comparison of the quality of life domains by the WHOQOL-OLD and self quality of life-analysis of subjects after intervention and baseline periods $(n=24)$.

\begin{tabular}{|c|c|c|c|c|c|}
\hline \multirow[b]{2}{*}{ Variables } & \multicolumn{4}{|c|}{ Period / Evaluation (minimum; median; maximum) } & \multirow[b]{2}{*}{$p$} \\
\hline & $\begin{array}{l}\text { Baseline "A"/ } \\
\text { First }\end{array}$ & $\begin{array}{l}\text { Intervention } \\
\text { "B"/Second }\end{array}$ & $\begin{array}{l}\text { Baseline "A"/ } \\
\text { Third }\end{array}$ & $\begin{array}{l}\text { Intervention } \\
\text { "B"/Fourth }\end{array}$ & \\
\hline Sensory functioning 1 & $6 ; 13 ; 19$ & $7 ; 13 ; 19$ & $7 ; 12 ; 18$ & $8 ; 14 ; 19$ & $<0.001$ \\
\hline Autonomy ${ }^{1}$ & $8 ; 15 ; 18$ & $10 ; 15 ; 18$ & $8 ; 12 ; 18$ & $9 ; 14 ; 18$ & $<0.001$ \\
\hline Past-present-future activities ${ }^{1}$ & $13 ; 15 ; 19$ & $13 ; 15 ; 19$ & $11 ; 14,5 ; 19$ & $13 ; 14,5 ; 19$ & $<0.001$ \\
\hline Social participation ${ }^{1}$ & $11 ; 15 ; 19$ & $12 ; 15 ; 19$ & $10 ; 13,5 ; 18$ & $10 ; 14,5 ; 20$ & $<0.001$ \\
\hline Death and dying ${ }^{1}$ & $4 ; 15,5 ; 20$ & $6 ; 16 ; 20$ & $4 ; 14,5 ; 20$ & $6 ; 15 ; 20$ & $<0.006$ \\
\hline Intimacy ${ }^{1}$ & $10 ; 16 ; 20$ & $12 ; 16 ; 20$ & $10 ; 14 ; 20$ & $11 ; 15 ; 20$ & $<0.001$ \\
\hline Health self-analysis ${ }^{2}$ & $1 ; 2 ; 3$ & $2 ; 3 ; 3$ & $1 ; 2 ; 3$ & $2 ; 3 ; 3$ & $<0.003$ \\
\hline Emotional situation self-analysis ${ }^{2}$ & $1 ; 2 ; 3$ & $1 ; 3 ; 3$ & $1 ; 2 ; 3$ & $1 ; 3 ; 3$ & $<0.004$ \\
\hline Body self-analysis ${ }^{2}$ & $1 ; 2 ; 3$ & $1 ; 3 ; 3$ & $1 ; 2 ; 3$ & $1 ; 2,5 ; 3$ & $<0.003$ \\
\hline Overall motility self-analysis ${ }^{2}$ & $1 ; 1 ; 3$ & $1 ; 3 ; 3$ & $1 ; 2 ; 3$ & $1 ; 2,5 ; 3$ & $<0.001$ \\
\hline Stress levels self-analysis ${ }^{3}$ & $1 ; 2 ; 4$ & $1 ; 3 ; 4$ & $1 ; 3 ; 4$ & $1 ; 2 ; 4$ & $<0.017$ \\
\hline
\end{tabular}

Note: ${ }^{1}$ Possible amplitude of the crude score in the quality of life domain $=16$, Minimum $=4$, Maximum $=20 ;{ }^{2}$ Score name: $1=$ weak, 2 $=$ regular, $3=$ good; ${ }^{3}$ Score name: $1=$ none, $2=$ little, $3=$ moderate, $4=$ very. 
The categorical classification of the average or median of WHOQOL-OLD can be used as low quality of life (scores below 10.9), average (11 to 14 ) and high quality of life (scores between 14.1 and 20) $(22,26,27)$.

The "Sensory Functioning" quality of life domain evaluates the sensory functioning and impact of the loss of sensory abilities on quality of life. After the final intervention, the median was 14 , considered average quality of life. The "Autonomy" domain was similar, with median 14 after intervention. The "Autonomy" domain refers to independence in the elderly stage. It describes how well older individuals are able to live independently and make their own decisions.

The domains that most contributed to the overall median of 15 in the WHOQOL-OLD were death / dying and intimacy. The "Death and Dying" domain is related to concerns, worries and fears about death and dying and the facet "Intimacy" assesses the ability to have personal and intimate relationships. Both domains showed high quality of life after intervention.

The "Past, Present and Future Activities" domain describes the satisfaction of achievements in life and things that one desires and "social participation" domain delineates participation in everyday activities, especially in the community. Both domains had median of 14.5 after the final intervention, classified with high quality of life.

\section{Discussion}

With the implementation of Pilates and conversation circles binomial, it was possible to increase the functional autonomy parameters and quality of life levels and reduce body mass index. Participants improved their emotional conditions, body harmony and global mobility. The reversibility factor between baseline (A) and intervention (B), an essential feature of this experimental design, excluded the influence of extraneous variables in the study. Thus, it was possible to ensure greater reliability among changes of dependent variables.

Regular physical exercise is an excellent strategy to reduce the negative effects of the aging process. Lacourt and Marini (28) found that strength, resistance and muscle power suffer significant decrease with advancing age and these losses can be considered factors that affect quality of life, functional capacity and independence among older people. The benefits of regular physical activity on health during the aging process include anthropometric, functional, neuromuscular, metabolic, cognitive and psychosocial effects, reducing falls and therapeutic effects and are effective in the treatment of several chronic diseases (29).

In the present study, BMI decreased after intervention with Pilates and conversation circles and increased after cessation. Fourie et al. (9) randomly distributed fifty older women into control group and intervention group with Pilates program for two months, three times a week. The intervention group significantly reduced body fat percentage and increased muscle mass. The control group showed no significant changes in any anthropometric variable.

Bird and Fell (3) investigated the effect of five weeks of physical training with Pilates method on the risk of falling among 30 older adults. The risk of falling was checked again after 12 months of training interruption. The authors found that Pilates would have a positive effect on the risk factors of physical decline in those who continued training compared to those who have ceased. After five weeks, the muscle strength of the lower limbs and the dynamic balance showed significant improvements. Significant effects were maintained after 12 months without training with Pilates method. After 12 months there were significant differences in balance and muscle strength among participants who continued performing Pilates and also for those who had ceased. After a short intervention with Pilates, the effect on balance could be observed one year later in all participants.

For the present study, the functional autonomy of participants, measured through a group of tests by the GDLAM protocol in the first assessment was compromised. They also reported difficulty in performing daily life activities. The functional autonomy improved after intervention and worsened when intervention ceased. When intervention with Pilates and conversation circles resumed, functional autonomy improved again.

Perez et al. (30) also found that older adults have reduced the time to carry out their functional activities. Sabatini (10) assessed 40 older women, one group being submitted to the Pilates method and the other not, for 20 weeks, once a week, and found out an improvement in the functional capacity, with positive effects on flexibility, muscle strength and balance.

Wells (31) sought to establish a consensus about indications, contraindications and precautions of Pilates exercise and its potential benefits. Professionals agreed that people who have little body awareness can benefit 
from Pilates exercise. They also agreed that the method can improve functional capacity, movement confidence, body awareness, posture and movement control. Other studies concluded that the method should be considered as a way to improve the quality of life of older adults (32).

In the present study regarding quality of life, it is possible that in the subjective responses of the WHOQOL-OLD questionnaire, high levels have occurred in the first assessment due to the need for social approval as a result of lack of connection with the interviewer at the beginning of the study. With the course of the study, with the creation of a relationship with the researcher and more knowledge about the instrument assessing quality of life, participants felt more comfortable to expose their reality. In our study, quality of life was considered medium or high for all domains and for all evaluations. Sensory functioning, autonomy and social participation were the domains that showed the most significant improvements.

The study of Sabatini (10) with 40 older women, one group submitted to Pilates method for 20 weeks once a week, and a control group, showed improvement in quality of life, with positive results in dimensions functional capacity, physical and emotional aspects and vitality, emotional and functional evaluation and final total score.

Most participants reported pain of weak and medium intensity in different parts of the body, which decreased throughout intervention. They also mentioned increased willingness to perform daily activities after intervention. In the study by Conte and Lopes (33), participants also reported feeling less pain and more willingness and energy to perform daily activities after intervention with physical exercises.

Conversation circles emerged in this population a link between the wish for living with better quality of life and expectations that the government could provide more effective health programs. Even not being evaluated, it is expected that participants have acquired knowledge, skills and important attitudes, inserting them in their habits. Melo et al. (34) found that health education programs have as a challenge the integration of various branches of human knowledge and biological areas of popular folk knowledge. Thus, new interfaces of action in the health care model aimed at well-being are proposed.

Anyway, between phases A and B, respectively in $1^{\text {st }}, 3^{\text {rd }}$ and $2^{\text {nd }}$ and $4^{\text {th }}$ evaluations, there were differences in the levels of quality of life and functional autonomy. Overall, the results tended to higher levels of self-reported quality of life after Pilates and conversation circles phases than at baseline.

The implementation of health education through conversation circles or other method, in combination with Pilates exercise should be encouraged in primary care. Thus, these practices will gain strength, ensuring benefits to the academic community and the general population. The insertion of Pilates in health promoting actions of primary care ensures the popularization of this method, sometimes considered elitist and the democratization of its positive effects on the human body. By promoting health and consequently preventing diseases, it reduces the number of individuals in the search for secondary and tertiary health care, which are more costly when compared to Pilates exercises and health education in primary health care.

\section{Conclusion}

With the implementation of the Pilates exercises and binomial conversation circles, it was possible to improve the functional autonomy and quality of life levels reducing body mass index. Participants improved their emotional conditions, body harmony and global mobility. The reversibility factor between baseline (A) and intervention periods (B), which is an essential feature of this experimental design, excluded the influence of extraneous variables. Thus, it was possible to ensure greater reliability among changes of dependent variables. The effect of Pilates method and conversation circles on health ensured improved functional autonomy and quality of life of participants.

There is a lack of studies in literature on the application of conversation circles in combination with Pilates method. This finding is unfortunate, as this combination of factors would bring important benefits to population, as observed in this study, although the precise identification of what was generated by the application of Pilates method and conversation circles is not clear. Further studies are required for the clarification of the results of these procedures in isolation. 


\section{References}

1. Brasil. Ministério da Saúde. Secretaria de Atenção à Saúde. Departamento de Ações Programáticas e Estratégicas. Atenção à saúde da pessoa idosa e envelhecimento. Área Técnica Saúde do Idoso. Brasília: Ministério da Saúde; 2010. Portuguese.

2. Brasil. Ministério da Saúde. Secretaria de Atenção à Saúde. Departamento de Atenção Básica. Envelhecimento e saúde da pessoa idosa. Brasília: Ministério da Saúde; 2006. Portuguese.

3. Bird ML, Fell J. Positive Long-Term Effects of Pilates Exercise on the Aged-Related Decline in Balance and Strength in Older, Community-Dwelling Men and Women. J Aging Phys Act. 2014;22(3):342-7.

4. Guimarães ACA, Azevedo SF, Simas JPN, Machado Z, Jonck VTF. Efeito do método Pilates na flexibilidade de idosos. Fisioter Mov. 2014;27(2):181-8.

5. Kolyniak IEGG, Cavalcanti SMB, Aoki MS. Avaliação isocinética da musculatura envolvida na flexão e extensão do tronco: efeito do método Pilates. Rev Bras Med Esporte. 2004;10(6):487-90.

6. Oliveira LC, Hoshina CS, Furlan LA, Oliveira RG, Martini FAN. 0 método Pilates no tratamento de espondilolistese traumática em L4-L5: estudo de caso. Fisioter Mov. 2013;26(3):623-9.

7. Roşu MO, Ţopa I, Chirieac R, Ancuta C. Effects of Pilates, McKenzie and Heckscher training on disease activity, spinal motility and pulmonary function in patients with ankylosing spondylitis: a randomized controlled trial. Rheumatol Int. 2014;34(3):367-72.

8. Lara S, Wendt P, Silva ML. Comparação da qualidade de vida em mulheres praticantes de Pilates e musculação. ConScientiae Saúde. 2014;13(1):134-40.

9. Fourie M, Gildenhuys GM, Shaw I, Shaw BS, Toriola AL, Goon DT. Effects of a mat Pilates programme on body composition in elderly women. West Indian Med J. 2013;62(6):524-8.

10. Sabatini NR. A influência do Método Pilates sobre a capacidade funcional, a qualidade de vida e a remodelação óssea em mulheres idosas [master's thesis]. Botucatu, SP (Brazil): Faculdade de Medicina de Botucatu da Universidade Estadual Paulista; 2014. 115 p. Portuguese.
11. Miyamoto GC, Costa LO, Cabral C. Efficacy of the Pilates method for pain and disability in patients with chronic nonspecific low back pain: a systematic review with meta-analysis. Braz J Phys Ther. 2013;17(6):517-32.

12. Brasil. Ministério da Saúde. Secretaria de Vigilância em Saúde. Vigitel Brasil 2013: vigilância de fatores de risco e proteção para doenças crônicas por inquérito telefônico/Ministério da Saúde, Secretaria de Vigilância em Saúde. Brasília: Ministério da Saúde; 2014. Portuguese.

13. Nahas MV. Atividade física, saúde e qualidade de vida: conceitos e sugestões para um estilo de vida ativo. 6th ed. Londrina (Brazil): Midiograf; 2013. 335 p. Portuguese.

14. Sampaio J, Santos GC, Agostini M, Salvador AS. Limits and potentialities of the circles of conversation: analysis of an experience with young people in the backcountry of Pernambuco, Brazil. Interface (Botucatu). 2014;18(Supl 2):1299-1311.

15. Correia N, Daniel JR, Aguiar C. Desenhos de investigação ABAB: uma abordagem experimental para a avaliação de intervenções em contextos naturais. Laboratório de Psicologia. 2014;12(1):15-30.

16. Coffito. Resolução noo.387, de 08 de junho de 2011. Fixa e estabelece os Parâmetros Assistenciais Fisioterapêuticos nas diversas modalidades prestadas pelo fisioterapeuta e dá outras providências [cited 2015 May 18]. Available from: http://coffito.gov.br/nsite/?p=1533.

17. Berbel NAN. A problematização e a aprendizagem baseada em problemas: diferentes termos ou diferentes caminhos. Interface (Botucatu). 1998;2(2):139-54.

18. Cyrino EG, Toralles-Pereira ML. Trabalhando com estratégias de ensino-aprendizado por descoberta na área da saúde: a problematização e a aprendizagem baseada em problemas. Cad Saúde Pública. 2004;20(3):780-8.

19. Costa RRO, Bosco Filho J, Medeiros SM, Silva MBM. As rodas de conversas como espaço de cuidado e promoção da saúde mental. Rev Aten Saúde. 2015;13(43):30-6.

20. Picolli F. Efeitos do treinamento proporcionado pelo método Pilates clássico nas aptidões físicas em mulheres saudáveis: um ensaio clínico controlado [master's thesis]. Porto Alegre (Brazil): Universidade Federal do Rio Grande do Sul; 2010.162 p. Portuguese.

21. Mendes PMV, Santos LE, Andrade Mesquita LS, Carvalho FT. Análise da funcionalidade e flexibilidade de mulheres em exercícios de pilates no solo. Arq Ciênc Saúde. 2015;22(3):53-7. 
22. Fleck MP, Chachamovich E, Trentini C. Development and validation of the Portuguese version of the WHOQOLOLD module. Rev Saúde Pública. 2006;40(5):785-91.

23. Dantas EHM, Vale RGS. Protocolo GDLAM de avaliação da autonomia funcional. Fit Perf J. 2004;3(3):175-82.

24. Alencar NA, Souza Jr JV, Aragão JCB, Ferreira MA, Dantas E. Nível de atividade física, autonomia funcional e qualidade de vida em idosas ativas e sedentárias. Fisioter Mov. 2010;23(3):473-81.

25. Vale RGS, Novaes JS, Dantas EHM. Efeitos do treinamento de força e de flexibilidade sobre a autonomia de mulheres senescentes. Rev Bras Ciênc Mov. 2005;13(2):33-40.

26. Fleck MPA, Chachamovich E, Trentini CM. Projeto WHOQOLOLD: método e resultados de grupos focais no Brasil. Rev Saúde Pública. 2003;37(6):793-9.

27. Borges LM, Seidl EMF. Saúde autopercebida e qualidade de vida de homens participantes de intervenção psicoeducativa para idosos. Psico USF. 2014;19(3):421-31.

28. Lacourt MX, Marini LL. Decréscimo da função muscular decorrente do envelhecimento e a influência na qualidade de vida do idoso: uma revisão de literatura. RBCEH. 2006;3(1):114-21.

29. Matsudo SM, Matsudo VKR, Marin RV. Atividade física e envelhecimento saudável. Diagn Tratamento. 2008;13(3):142-7.
30. Pérez VSC, Haas AN, Wolff SS. Analysis of activities in the daily lives of older adults exposed to the Pilates Method. J Bodyw Mov Ther. 2014;18(3):326-31.

31. Wells C, Kolt GS, Marshall P, Bialocerkowski A. Indications, benefits, and risks of Pilates exercise for people with chronic low back pain: a Delphi survey of Pilates-trained physical therapists. Phys Ther. 2014;94(6):806-17.

32. Bullo V, Bergamin M, Gobbo S, Sieverdes JC, Zaccaria $M$, Neunhaeuserer D, et al. The effects of Pilates exercise training on physical fitness and wellbeing in the elderly: a systematic review for future exercise prescription. Prev Med. 2015;75:1-11.

33. Conte EMT, Lopes AS. Qualidade de vida e atividade física em mulheres idosas. RBCEH. 2005;2(1):61-75.

34. Melo MC, Souza AL, Leandro EL, Arruda Mauricio H, Silva ID, Oliveira JMO. A educação em saúde como agente promotor de qualidade de vida para o idoso. Ciênc Saúde Coletiva. 2009;14(Suppl 1):1579-86.

Received in 07/10/2015

Recebido em 10/07/2015

Approved in 12/18/2015

Aprovado em 18/12/2015 